\title{
Expression of EGFR family and p53 in a patient with Synchronous Primary Endometrial Adenocarcinoma and Clear Cell Renal Carcinoma: a Case Report
}

\author{
Expressão da família EGFR e p53 em paciente com Adenocarcinoma Endometrial e \\ Carcinoma Renal de Células Claras primários e sincrônicos: Relato de Caso \\ Priscila Fernanda da Silva Martins ${ }^{1}$, Izabella Cristina Alves Souza', Enio Ferreira², Emerson Soares \\ Veloso ${ }^{2}$, Tatiany L Silveira ${ }^{2}$, Adam Underwood ${ }^{3}$, Fabiano Conde Araujo ${ }^{4}$, Helen Lima Del-Puerto ${ }^{2}$
}

\begin{abstract}
We present a case of a 69 year-old, non-obese, post-menopausal woman diagnosed with synchronous endometrial adenocarcinoma and renal cell carcinoma. Immunolocalization and expression of the EGFR, HER-2, HER-3, HER-4 and p53 proteins by immunohistochemistry $(\mathrm{IHC})$ was performed to investigate synchronous expression of these proteins. The endometrial adenocarcinoma was a well-differentiated tumor, with discernable glandular structure with moderate mitotic index. IHC revealed weak HER-2, HER-3 and HER-4 staining of cell membranes in well-differentiated areas, and intense HER-2 and p53 staining in papillary areas. The renal cell carcinoma showed clear cell type, solid tumor, Fuhrman nuclear grade 2, presence of necrosis and hemorrhage. IHC revealed intense HER-2 and HER-4 staining of cell membranes, weak EGFR staining, and negative expression for HER3 and p53 protein. In summary, overexpression of HER-2 and HER-4 may correlate with histological grade of the tumor and patient prognosis.
\end{abstract}

Keywords: Endometrial carcinoma; Renal clear cell carcinoma; EGFR family; p53

\footnotetext{
1. Centro Universitário UNA, Instituto de Ciências Biológicas e da Saúde - Belo Horizonte - Minas Gerais - Brazi

2. Universidade Federal de Minas Gerais, Departamento de Patologia - Belo Horizonte - Minas Gerais - Brazil

3. Walsh University, Division of Math and Science - North Canton - Ohio - United States

4. Faculdade de Medicina, Faminas-BH, Departamento de Medicina - Belo Horizonte - Minas Gerais - Brazil
}

Financial support: CNPq and Fapemig.

Conflicts of interest: The authors declare no conflict of interest relevant to this manuscript.

Correspondence author: Helen Lima Del Puerto. Universidade Federal de Minas Gerais, Departamento de Patologia - Instituto de Ciências

Biológicas - Av. Pres. Antônio Carlos, 6627 - Pampulha, Belo Horizonte - MG, 31270-901. helendelpuerto@hotmail.com 


\section{RESUMO}

Apresentamos um relato de caso de uma paciente com 69 anos, não-obesa, pós-menopausa, diagnosticada com adenocarcinoma endometrial simultâneo ao carcinoma de células renais. A imunolocalização e expressão das proteínas EGFR, HER-2, HER-3, HER-4 e p53 através de imunohistoquímica (IHC) foi realizada para investigar a simultaneidade na expressão dessas proteínas em ambos tumores. O adenocarcinoma endometrial era um tumor bem diferenciado, com estruturas grandulares discerníveis e com índice mitótico moderado. A IHC revelou fraca marcação das proteínas HER-2, HER-3 e HER-4 nas membranas celulares em áreas bem diferenciadas, e marcação intensa de HER-2 e p53 em áreas papilares. O carcinoma de células renais apresentou tipo células clara, tumor sólido, grau 2 de malignidade nuclear, presença de necrose e hemorragia. IHC revelou marcação intensa de HER-2 e HER-4 nas membranas celulares, fraca de EGFR e negativa para HER-3 e p53. Em resumo, a super expressão das proteínas HER-2 e HER-4 podem estar correlacionadas ao grau histológico dos tumores e ao prognóstico da paciente.

Descritores: Carcinoma Endometrial; Carcinoma renal de células claras; Família EGFR; p53

\section{INTRODUCTION}

When patients have more than one tumor in the same or different organs/tissues, it is expected a hereditary predisposition to multiple tumors. Overall, based on an analysis of several studies, the incidence of multiple primary tumors is reported to be around 0.73-5.2\%.(1) In patients diagnosed with two malignancies simultaneously, a major challenge is to find an anticancer therapy strategy to treat both cancer types without increasing toxicity or pharmacological interactions, and without negative impact on overall outcome. ${ }^{(2,3)}$ Caucasian ancestry, cancer diagnostic at younger age, lower grade with indolent clinical behavior with longer survival, and cancer family history are reported as risk factors for multiple primary tumors. ${ }^{(1)}$

Human epidermal growth factor receptor (HER) family members have been shown to be involved in oncogenesis in a number of human cancers. ${ }^{(4)}$ In endometrial cancer, the expression of EGFR has been noted in $43-67 \%$ of cases and is associated with a decrease in disease-free and overall Survival.(4) In renal cell carcinoma (RCC) EGFR expression is higher in primary RCC specimens compared with benign renal parenchyma, indicating its possible role in tumor development and progression. ${ }^{(5)}$ EGFR expression is often heterogeneous within clear cell RCC, where it has been described as negative, weakly positive, and strongly positive staining. ${ }^{(6)}$

Normal endometrium had a mild HER-2 protein expression regardless of the phase of the menstrual cycle.(7) In endometrial cancer the HER-2 expression directly correlates with disease stage, grade, and non-endometrioid tumor subtype, suggesting that HER-2 has potential use as a biomarker for predicting disease stage, tumor aggressiveness and prognosis. ${ }^{(7)}$
Normal endometrial glands and stroma show weak to moderate expression of HER-4. HER-4 and its ligands have also been noted to be more highly expressed during the secretory phase versus the proliferative phase of the menstrual cycle, suggesting a possible involvement in maturation and anti-proliferative effects in the endometrium. HER-4 is expressed at a lower level in endometrial cancer and is overexpressed in approximately $15 \%$ of cases. ${ }^{(8)}$ Furthermore, Thomasson et al. ${ }^{(9)}$ evaluated HER-4 gene and protein expression in normal kidney parenchyma compared to renal carcinomas from 31 patients and observed that HER-4 mRNA expression in RCC tumor tissue was significantly reduced compared with normal matched kidney cortex. ${ }^{(9)}$

Therefore, the aim of the present study it was to correlate synchronous immunohistochemistry expression of the EGFR family and p53 in a synchronous endometrial and renal primary tumor, and also correlate with tumors grade and histological characteristics.

\section{Case description}

The patient was a 69 year-old, non-obese, post-menopausal woman, with no vaginal bleeding, abdominal pain or urinary symptoms. She was diagnosed with synchronous endometrial adenocarcinoma and clear cells renal cell carcinoma (RCC), and anatomopathological characteristics of tumors are describe on Table 1. Of note in her medical history, she regularly took medications with paracetamol for back pain. She has a sister with a history of breast cancer at age 54, diagnosed as invasive ductal carcinoma grade II (cancer-free for sixteen years), and a brother who died at age 83 with grade 2 follicular lymphoma. The patient in the present study has been cancer-free since surgery 4 years ago; no other treatment was advised besides regular follow up imaging. 
Table 1. Anatomopathological characteristics of tumors.

\begin{tabular}{lll}
\hline & Endometrium & Kidney \\
\hline Histological type & Endometrioid adenocarcinoma & Clear cells renal cell carcinoma \\
Histological grade & Well differentiated & Grade 1 \\
Nuclear grade & Grade 2 & Fuhrman grade 2 \\
Mitotic index & Moderated & Not describe \\
Necrosis & Absent & Present \\
Hemorrhage & Not describe & Present \\
Invasion/Infiltration & Vascular infiltration - not observed & Kidney capsule - absent \\
& Myometrium invasion - superficial and focal & Perirenal fat - absent \\
TNM & Endocervical infiltration - absent & Renal pelvis - absent \\
\hline
\end{tabular}

Protein expression analysis was performed in both tumors of this patient, and fixed paraffin-embedded tissue sections were processed for immunohistochemistry (IHC) staining using the ABC (avidin-biotin complex) method, following the protocol shown in Table 2. As a positive IHC control for EGFR, HER-2, HER-3 and HER-4, canine mammary specimens were used (Figure 1), in a well-established routine protocol in collaboration with the Comparative Pathology Laboratory at UFMG (Laboratório de Patologia Comparada - LPC) (Figure 1).

Results from endometrial adenocarcinoma IHC staining confirmed a well-differentiated tumor (FIGO grade 1), with an epithelial growth pattern, areas of budding and branching of glands forming papillary structures, endometrioid type, nuclear grade 2, and with moderate mitotic index. Results from the renal cell carcinoma confirmed a clear cell type, solid tu- mor, Fuhrman nuclear grade 2, with areas of necrosis and hemorrhage.

In the present investigation HER-2, HER-4 and EGFR expression was present in both primary tumors. HER-2 was weakly expressed in both endometrioid and renal cell carcinomas. However, HER-4 was localized in nuclei of the renal cell carcinoma (Figure $3)$, with $50 \%$ positive staining of the tubules and glomerulus (Figure 3), although the endometrioid adenocarcinoma revealed an intense membrane staining (Figure 3). EGFR expression in clear cells RCC was positive, with moderate membranous staining in $90 \%$ of the cells (Figure 2), and in the endometrioid adenocarcinoma EGFR stained weakly in epithelial cells (Figure 2).

No HER-3 expression was evident, and p53 was detected only in the papillary areas of the endometrioid adenocarcinoma (Figures 2 and 3).

Table 2. IHC parameters for polyclonal EGFR, HER-2, HER-3, HER-4 and p53 antibody.

\begin{tabular}{|c|c|c|c|c|}
\hline Antibody & Antigen Retrieval & Dilution & Incubation & Source \\
\hline EGFR & Pepsin $+37^{\circ} \mathrm{C}$ & $1: 50$ & ON & Dako \\
\hline HER2 & Citrate buffer + WB & $1: 200$ & ON & Dako \\
\hline HER3 & EDTA + WB & $1: 100$ & $30^{\prime}$ & Dako \\
\hline HER4 & Citrate buffer + Pascal & $1: 100$ & ON & Dako \\
\hline p53 & Citrate buffer + Pascal & $1: 400$ & ON & Dako \\
\hline
\end{tabular}

* WB - Water bath; ON - Overnight, Pascal - pressure cooker. 
EGFR

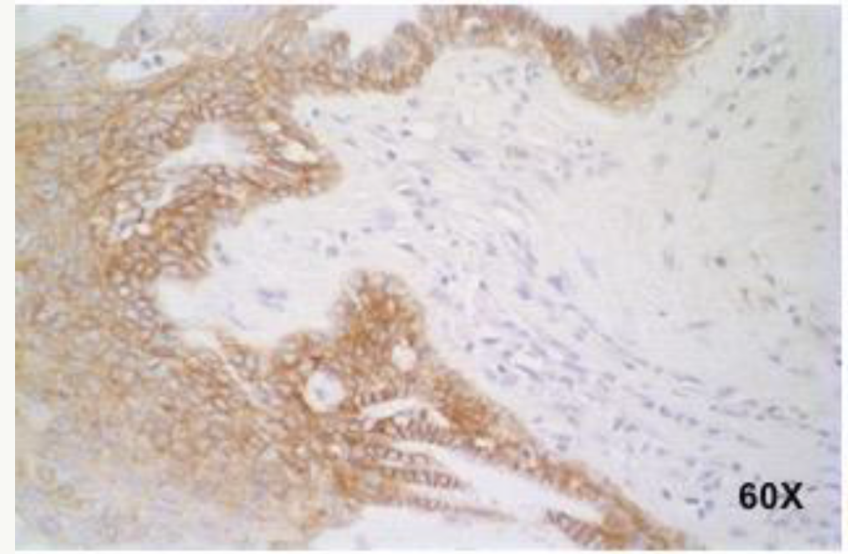

HER-3

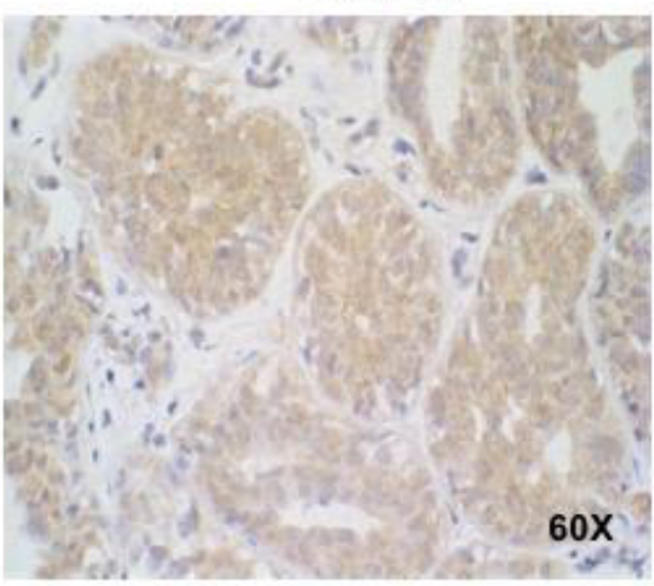

HER-2

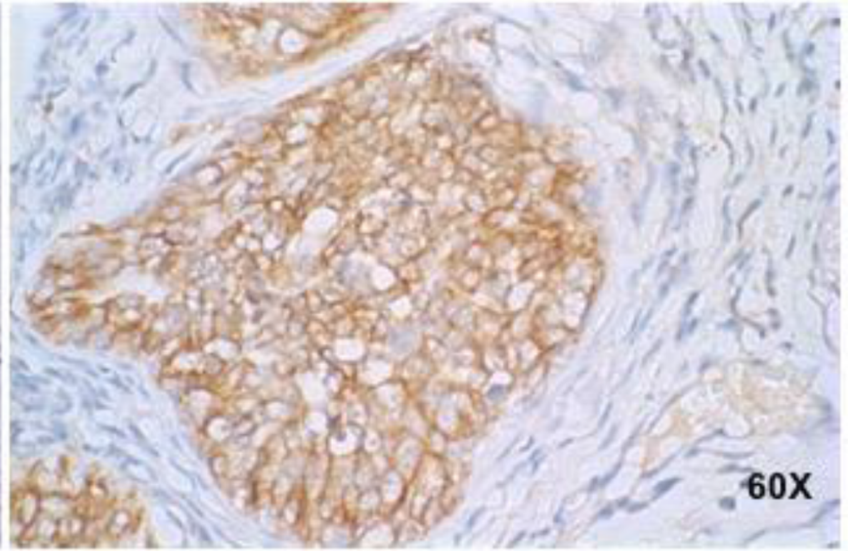

HER-4

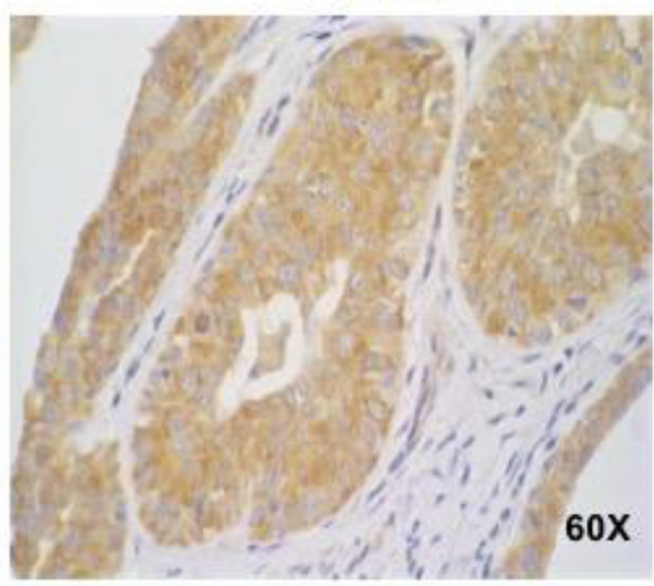

Figure 1. Immunohistochemistry (IHC) positive protocol for EGFR, HER-2, HER-3 and HER-4. Canine mammary specimens. 


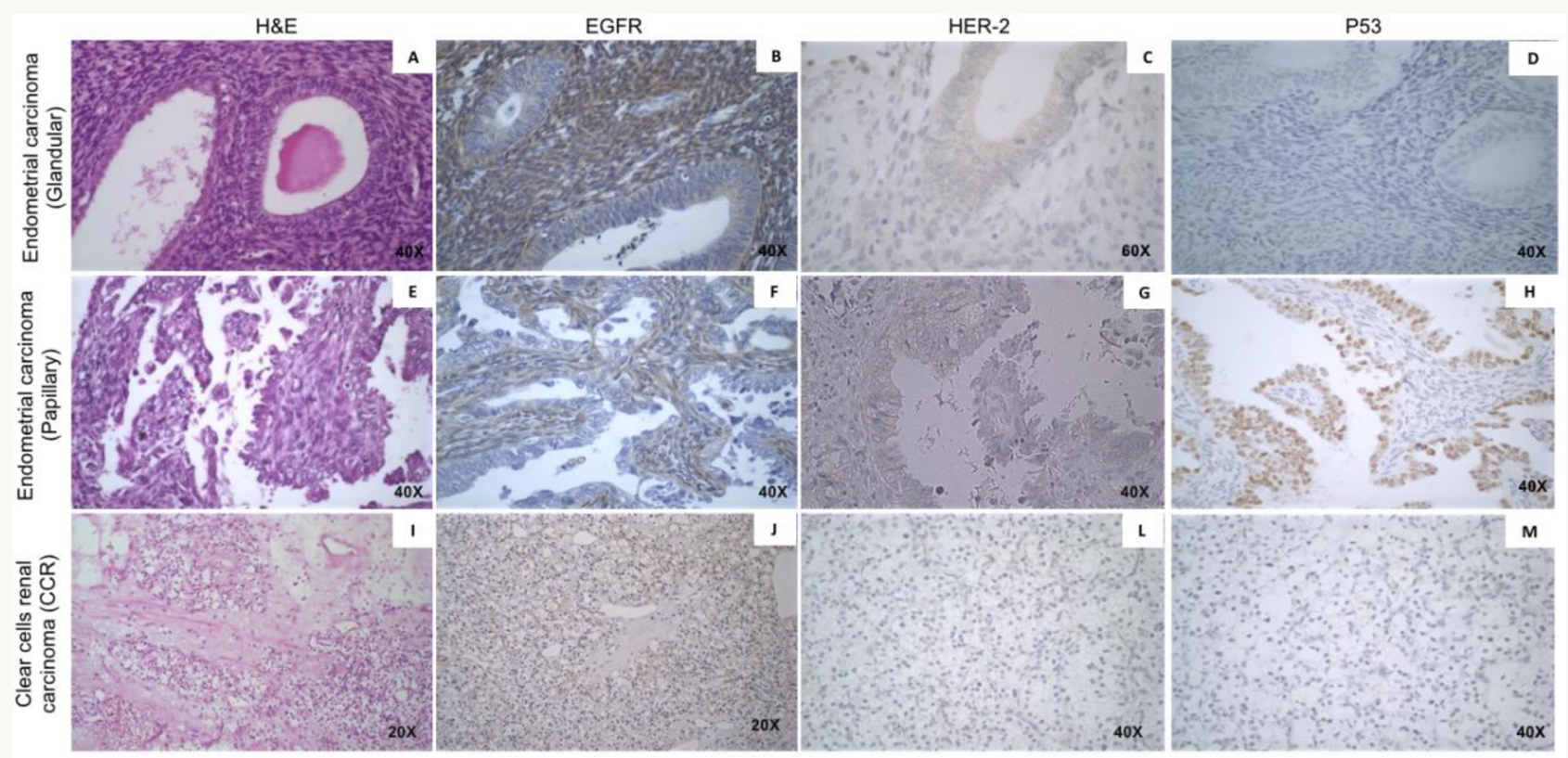

Figure 2. Immunohistochemistry (IHC) for EGFR, HER-2 and p53 in endometrial carcinoma and clear cell renal carcinoma. A: H\&E - endometrial carcinoma glandular area. B: EGFR IHC - Intense staining of EGFR in stromal area, and weak staining in glandular area of endometrial carcinoma. C: HER-2 IHC - Weak staining of HER-2 in endometrial carcinoma glandular area. D: p53 IHC - negative staining of p53 in endometrial carcinoma glandular area. E: H\&E - endometrial carcinoma papillary area. F: EGFR IHC - Moderate staining of EGFR in stromal area, and negative staining in epithelial cells of endometrial carcinoma papillary area. G: HER-2 IHC - Negative staining of HER-2 in endometrial carcinoma papillary area. H: p53 IHC - Intense staining of p53 in endometrial carcinoma papillary area. I: H\&E - Clear cells renal carcinoma. J: EGFR IHC - moderate staining of EGFR in CCR. L: HER-2 IHC - Weak staining of HER-2 in CCR. M: p53 IHC - negative staining of p53 in CCR.
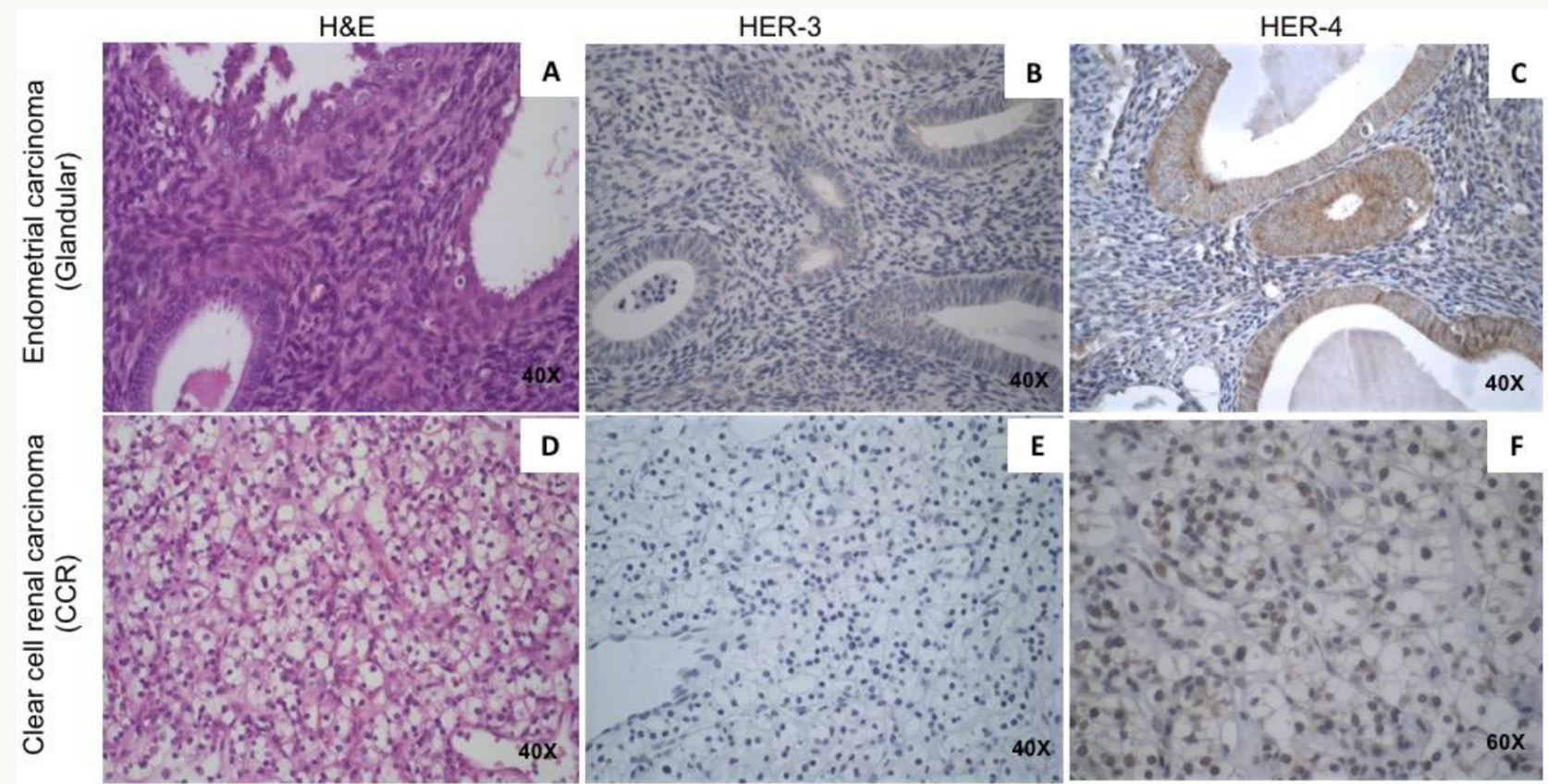

Figure 3. Immunohistochemistry (IHC) for HER-3 and HER-4 in endometrial carcinoma and clear-cell renal carcinoma. A: H\&E - endometrial carcinoma glandular area. B: HER-3 IHC - negative staining of HER-3 in stromal area of endometrial carcinoma glandular area. C: HER-4 IHC - Intense staining of HER-4 in endometrial carcinoma glandular area. D: H\&E - Clear cells renal carcinoma. E: HER-3 IHC - negative staining of HER-3 in CCR. F: HER-4 IHC - Nuclear positive staining of HER-4 in CCR. 


\section{DISCUSSION}

HER-2 expression is associated with high grade endometrioid adenocarcinoma, and HER-2 overexpression is linked to poor prognostics because of a more aggressive tumor behavior. ${ }^{(10,11)}$ In the present investigation HER-2 was weakly expressed in endometrioid adenocarcinoma, and this $\mathrm{IHC}$ result is in accordance to the patient good prognosis, since she has been cancer-free for 4 years, and with patient's tumor histological grade. With regard to the RCC, our results showed that HER-2 expression is rare in clear cells renal cell carcinoma, in accordance to Wang et al. (2012) that showed a reduced HER-2 expression during the development, oncogenesis and progression of RCC. ${ }^{(12)}$

According to Thomasson et al. (2004), ${ }^{(9)}$ HER-4 is a tumor suppressor in most RCCs, and it is related with a good prognosis. In addition, Srinivasan et al. (1999)(8) showed HER-4 overexpression in endometrioid adenocarcinoma compared to normal endometrium. In clear cell RCC evaluated in the present study, HER4 was localized in nuclei of the clear cells RCC, and endometrioid adenocarcinoma revealed an intense HER-4 membrane staining (Figure 3).

EGFR receptor overexpression is related to initiation and tumor progression in $\mathrm{RCC}_{1}^{(13)}$ and in the present patient it was observed $90 \%$ of clear cells RCC with EGFR moderate staining, indicating its relation to tumor initiation. EGFR protein is normally expressed in normal glandular endometrium, and EGFR could play a dual role in endometrial carcinoma, such that high EGFR expression in type I carcinoma is associated with low grade and favorable outcomes, but in contrast, EGFR expression in type II carcinoma was associated with high grade and adverse clinical outcome. ${ }^{(14-17)}$

The p53 mutation in endometrial carcinoma is related to tumor survival and metastasis risk, ${ }^{(18)}$ however, in the endometrioid adenocarcinoma it was observed p53 immunostaining only in papillary area of the tumor. At the present investigation in clear cells RCC p53 expression was negative (Figure 2), but nevertheless p53 expression is considered rare in clear cells RCC, in relation to other types of renal carcinomas. ${ }^{(19)}$

In conclusion, HER-2, HER-4 and EGFR proteins were found synchronously expressed in both primary tumors, and their expression in the present study is consistent with their histological grade and patient cancer-free status, and it is also in accordance to literature on the HER-2, HER-4 and EGFR proteins expression behavior in both tumors. Future studies to investigate genetic instability in EGFR family DNA sequence may clarify if the synchronous proteins expression in both primary tumors it is an important trigger for cancer in those cases.

\section{ACKNOWLEDGMENTS}

Informed consent was obtained from the patient, and the study was approved by the local ethics committee at UNA (CAAE: 69101517.5.0000.5098, process number: 2.381.949). Preliminary results were presented at the $127^{\text {th }}$ Annual Meeting of The Ohio Academy of Science (OAS) and published at the meeting proceedings (The Ohio Journal of Science, 118(1):A-42, 2018). The authors are indebted to Dr. Amy Milsted for her helpful review of the OAS abstract and final manuscript. Research funded by FAPEMIG, Brazil.
Author's contribution: H. L. D. P., E. F, F.C.A and A. $C$. U. conceived and planned the experiments, guided the students, contributed to the interpretation of the results and took the lead in writing the manuscript; I. C. A. S.; P. F. S. M; E. S. V. and T. L. S. carried out the experiment and contributed to the interpretation of the results. All authors provided critical feedback and helped shape the research, analysis and manuscript.

\section{REFERENCES}

1. Li F, Zhong WZ, Niu FY, Zhao N, Yang J, Yan HH, et al. Multiple primary malignancies involving lung cancer. BMC Cancer. 2015;15:696-703.

2. Ferri JVV, Gornatti VP, Martins TV. Malignidades primárias sincrônicas de pulmão e reto: relato de caso e revisão da literatura. Revista de Medicina. 2016;95:152-155.

3. Warren S, Gates O. Multiple primary malignant tumors. Am J Cancer. 1932;16:1358-1414.
4. Konecny GE, Venkatesan N, Yang G, Dering J, Ginther C, Finn R, et al. Activity of lapatinib a novel HER2 and EGFR dual kinase inhibitor in human endometrial cancer cells. $\mathrm{Br} J$ Cancer. 2008;98(6):1076-84.

5. Merseburger AS, Hennenlotter J, Simon P, Kruck $\mathrm{S}$, Koch E, Horstmann M, et al. Membranous expression and prognostic implications of epidermal growth factor receptor protein in human renal cell cancer. Anticancer Res. 2005;25:19011908. 
6. Cohen D, Lane B, Jin T, Magi-Galluzzi C, Finke J, Rini $\mathrm{Bl}$, et al. The prognostic significance of epidermal growth factor receptor expression in clear cell renal cell carcinoma: A call for standardized methods for immunohistochemical evaluation. Clin Genitourin Cancer. 2007;5(4): 264-270.

7. Reyes HD, Thiel1 KW, Carlson MJ, Meng X, Yang $\mathrm{S}$, Stephan J-M, et al. Comprehensive profiling of EGFR/HER receptors for personalized treatment of gynecologic cancers. Mol Diagn 3 Ther. 2014;18(2):137-151.

8. Srinivasan R, Benton E, McCormick F, Thomas $H$, Gullick WJ. Expression of the c-erbB-3/HER-3 and c-erbB-4/HER-4 growth factor receptors and their ligands, neuregulin-1 alpha, neuregulin-1 beta, and betacellulin, in normal endometrium and endometrial cancer. Clin Cancer Res. 1999;5:2877-2883.

9. Thomasson $\mathrm{M}$, Hedman $\mathrm{H}$, Junttila TT, Elenius $\mathrm{K}$, Ljungberg B, Henriksson R. ErbB4 is downregulated in renal cell carcinoma--a quantitative RTPCR and immunohistochemical analysis of the epidermal growth factor receptor family. Acta Oncol. 2004;43:453-459.

10. Morrison C, Zanagnolo V, Ramirez N, Cohn DE, Kelbick N, Copeland L, et al. HER-2 is an independent prognostic factor in endometrial cancer: association with outcome in a large cohort of surgically staged patients. J Clin Oncol. 2006;24:2376-2385.

11. Stumm G, Eberwein $S$, Rostock-Wolf $S$, Stein $H$, Pomer S, Schlegel J, et al. Concomitant overexpression of the EGFR and erbB-2 genes in renal cell carcinoma (RCC) is correlated with differentiation and metastasis. Int J Cancer. 1996;69:17-22.

12. Wang H, Liu C, Han J, Zhen L, Zhang T, He X, et al. HER2 expression in renal cell carcinoma is rare and negatively correlated with that in normal renal tissue. Oncol Lett. 2012;4:194-198.
13. Dorđević $G$, Matušan Ilijaš $K$, Hadžisejdić I, Maričić A, Grahovac B, Jonjić N. EGFR protein overexpression correlates with chromosome 7 polysomy and poor prognostic parameters in clear cell renal cell carcinoma. J Biomed Sci. 2012;19:40.

14. Berchuck A, Soisson AP, Olt GJ, Soper JT, Clarke-Pearson DL, Bast RC, et al. Epidermal growth factor receptor expression in normal and malignant endometrium. Am J Obstet Gynecol. 1989;161:1247-1252.

15. Latif Z, Watters AD, Bartlett JMS, Underwood MA, Aitchison M. Gene amplification and overexpression of HER2 in renal cell carcinoma. BJU Int. 2002;89:5-9.

16. Niikura H, Sasano H, Kaga K, Sato S, Yajima A. Expression of epidermal growth factor family proteins and epidermal growth factor receptor in human endometrium. Hum Pathol. 1996;27:282-289.

17. Konecny GE, Santos L, Winterhoff B, Hatmal M, Keeney GL, Mariani A, et al. HER2 gene amplification and EGFR expression in a large cohort of surgically staged patients with non-endometrioid (type II) endometrial cancer. Br J Cancer. 2009;100:89-95.

18. Masjeed NMA, Khandeparkar SGS, Joshi AR, Kulkarni MM, Pandya N. Immunohistochemical Study of ER, PR, Ki67 and p53 in Endometrial Hyperplasias and Endometrial Carcinomas. J Clin Diagn Res. 2017;11:31-34.

19. Hodorova I, Solar P, Mihalik J, Vecanova J, Adamkov M, Rybarova S. Investigation of tumour supressor protein p53 in renal cell carcinoma patients. Biomed Pap Med Fac Univ Palacky Olomouc Czech Repub. 2014;158:44-49. 